\title{
THE FLAMINGO IN THE BAHAMAS
}

\section{Protection Society Formed}

The National Audubon Society of New York has been much concerned with the survival of the American flamingo (Phonicopterus ruber). It has therefore appointed Mr. Robert $\mathbf{P}$. Allen, a Research Associate, to make a complete survey of the status of this flamingo and to co-operate in its protection with individual organizations and governments in the countries concerned.

Of the past and present range of this flamingo Mr. Allen writes that it extended from the Mexican Gulf coast on the west, to Abaco, in the northern Bahamas, throughout these islands southward to the greater Antilles (including such outlying points as Jamaica, Puerto Rico, the Virgin Islands, and Antigua), to Curacao, the coast of Venezuela, the Guianas to Cayenne and east central Brazil. There was (and still may be) a small colony on Charles Island, in the Galapagos. To-day the flamingo has been so reduced in numbers that there are many times more deserted breeding sites than living colonies. The total number that now survives is only some 15,000 birds, which would have been equalled by the previous population of a single large colony.

The present population is scattered over the Bahamas, Cuba, Hispaniola and Yucatan, with a small group apparently clinging to existence within the Dutch colony at Curacao, and the doubtful possibility that a handful survives at Charles Island, in the Galapagos. Only six or seven nesting localities are known and only two of these are of any consequence-those on Inagua, in the Bahamas, and at Punta Meco, in Yucatan. Roughly about 53 per cent of the population breeds in the Bahamas, 26 per cent in Yucatan, and 16 per cent in Cuba. The remainder occur as non-breeding or uncertainly breeding birds elsewhere.

The critical place for the survival of the American flamingo is certainly the Bahamas. Besides the still existing colony of some 7,500 on Inagua Island, there was until 1940 one of 10,000 on the southern tip of Andros. Now this has vanished, the loss being attributed to the taking of the eggs and young by local people and to disturbance by low-flying aeroplanes. Yet the habitat has not been altered and there is every reason to believe that with adequate protection the flamingos will return.

During April this year Mr. Allen paid a long visit to the Inagua flamingo colony and writes as follows : "It was a magnificent display. Some 2,000 adults were sitting on nests in the major 
concentration (near Horse Cay) and a smaller group seemed to be starting to build in a curving bight to the south. All about, almost as far as the eye could see, many hundreds of other flamingos were scattered in feeding positions. Farther to the east, out of view towards the Upper Lobes, it is probable that even greater numbers were nesting." Mr. Allen makes it clear that the same factors which caused the disappearance of the flamingos from Andros are adversely affecting them at Inagualow-flying aircraft and the taking of eggs and young for food. Legally the flamingo is fully protected throughout the Bahamas from Ist April to 1st October.

In the Bahamas the response to the appeal to save the flamingo has been most gratifying. The Society for the Protection of the Flamingo in the Bahamas has been formed, under the patronage of His Excellency The Governor, Major-General Robert Neville, C.B.E., R.M. The founders include many of the leaders of the cultural and business life of the islands, among them Mr. L. E. W. Forsythe, O.B.E. (President), and Mr. Arthur S. Vernay (Chairman). The Society has also the support of many distinguished scientists among its Honorary Founders. Included among these are Mr. John H. Baker (President, National Audubon Society of New York), Dr. David Bannerman, British Museum of Natural History, Dr. Robert Cushman Murphy, and Mr. Richard H. Pough, of the American Museum of Natural History. Valuable work is being done by the Treasurer, Mr. P. G. D. Bethell, M.H.A., and by the Secretary, Mr. George S. Morley.

The new Society has lost no time in getting to work. Sufficient members have been enrolled and money collected to make an excellent start. Following Mr. Allen's survey, wardens have been enlisted and have been appointed as special constables. Outboard motors and other necessary equipment have been bought. Low flying by aeroplanes over the breeding grounds has been checked. In fact a vigorous campaign is already in progress and there is every hope that not only will the flamingo be saved in the Bahamas, but that it will be restored in numbers and its old haunts occupied once again.

The address of the Society for the Protection of the Flamingo is : c/o Paul S. Potter, The Royal Bank of Canada, Nassau, N.P., Bahamas. 